\title{
PENGARUH KOMPETENSI DAN MOTIVASI TERHADAP KINERJA PEGAWAI POS PEMBINAAN TERPADU (POSBINDU) KABUPATEN TABALONG
}

\author{
Heldina Sofia \\ Sekolah Tinggi Ilmu Ekonomi Pancasetia \\ Jl. Ahmad Yani Km. 5.5 Banjarmasin \\ tabalonghusada@yahoo.co.id
}

\begin{abstract}
Penelitian ini bertujuan untuk mengetahui baik secara parsial dan simultan seberapa besar Pengaruh Kompetensi Dan Motivasi Terhadap Kinerja Pegawai Pos Pembinaan Terpadu (POSBINDU) Kabupaten Tabalong serta variabel yang berpengaruh dominan terhadap Kinerja Pos Pembinaan Terpadu (POSBINDU) Kabupaten Tabalong, Metode yang digunakan dalam penelitian ini adalah metode kuantitatif dan dengan populasi sebanyak 80 (delapan puluh), diambil sampel dengan sensus sebanyak 80 (delapan puluh) orang, instrument penelitian uji validitas dan uji reliabilitas, data - data diuji dengan menggunakan regresi linear berganda. Hasil penelitian ini menunjukkan bahwa (1) Kompetensi dan Motivasi berpengaruh signifikan secara parsial terhadap Kinerja Pos Pembinaan Terpadu (POSBINDU) Kabupaten Tabalong (2) Kompetensi dan Motivasi berpengaruh signifikan secara simultan terhadap Kinerja Pos Pembinaan Terpadu (POSBINDU) Kabupaten Tabalong dan (3) Motivasi merupakan variabel yang berpengaruh dominan terhadap Kinerja Pos Pembinaan Terpadu (POSBINDU) Kabupaten Tabalong. R Square sebesar 0,561 yang berarti besarnya variasi sumbangan seluruh variabel bebas terhadap variabel terikatnya adalah 56,1\% sedangkan sisanya $43,9 \%$ dijelaskan oleh sebab lain diluar dari penelitian ini.
\end{abstract}

\section{Kata Kunci : Kompetensi, Motivasi dan Kinerja Pegawai}

\section{PENDAHULUAN}

Untuk dapat meningkatkan derajat kesehatan masyarakat banyak hal yang perlu dilakukan, salah satu diantaranya dengan menyelenggarakan pelayanan kesehatan. Pelayanan kesehatan adalah setiap upaya yang diselenggarakan sendiri atau secara bersama-sama dalam suatu organisasi untuk memelihara dan meningkatnya kesehatan perorangan, keluarga, kelompok ataupun masyarakat. Dalam objek penelitian ini adalah pegawai Pos Pembinaan Terpadu (POSBINDU) Kabupaten Tabalong yang diharapkan memberikan pelayanan kesehatan kepada masyarakat di Kabupaten Tabalong lebih baik lagi kedepannya, untuk itu perlu peningkatan Kompetensi dan Motivasi kepada pegawai agar pegawai dapat bekerja dengan baik.

Kompetensi kerja merupakan suatu ketrampilan yang dimiliki oleh seseorang terhadap segala aspek pekerjaan yang akan dijalankan dan ketrampilan tersebut membuatnya merasa mampu untuk bisa mencapai berbagai tujuan dalam pekerjaanya. Kompetensi mempunyai arti yang sama dengan kata kemampuan kecakapan atau keahlian. Rosyadi dan Muwarti (2005:12) menyatakan bahwa kompetensi dalam suatu situasi tidak dapat digunakan untuk memperkirakan kompetensi dalam situasi lain.

Peran kompetensi sangat diperlukan dalam prestasi kerja pegawai. Pegawai yang mempunyai kompetensi kerja yang baik tentu akan mudah untuk melaksanakan semua tanggung jawab pekerjaan. Mampu membaca situasi dan permasalahan yang terjadi dalam pekerjaan serta dapat memberikan respon yang tepat dan memiliki penyesuaian diri yang baik dengan lingkunganya. Sebagai seorang contoh seorang yang pada awalnya mempunyai prestasi kerja yang berupa karir menduduki posisi jabatan tertentu misalnya supervisor, kemudian melewati 
banyak situasi dan peluang yang terhampar selama menyusuri perjalanan kariernya dapat berbelok dan diantaranya yang melompat menduduki jabatan manajerial. Tetapi banyak pula yang tepat dijalur profesi supervisor, karena mengalami stagnasi dalam perkembangan karirnya, tentu saja hal ini perlu diketahui mengapa pegawai tersebut tidak dapat meningkatkan prestasinya.

Kompetensi kerja merupakan suatu keterampilan yang dimiliki oleh seseorang terhadap segala aspek pekerjaan yang akan dijalankan dan ketrampilan tersebut membuatnya merasa mampu untuk bisa mencapai berbagai tujuan dalam pekerjaanya. Kompetensi mempunyai arti yang sama dengan kata kemampuan kecakapan atau keahlian.

Rosyadi dan Muwarti (2005:12) menyatakan bahwa kompetensi dalam suatu situasi tidak dapat digunakan untuk memperkirakan kompetensi dalam situasi lain. Peran kompetensi sangat diperlukan dalam prestasi kerja pegawai. Pegawai yang mempunyai kompetensi kerja yang baik tentu akan mudah untuk melaksanakan semua tanggung jawab pekerjaan. Mampu membaca situasi dan permasalahan yang terjadi dalam pekerjaan serta dapat memberikan respon yang tepat dan memiliki penyesuaian diri yang baik dengan lingkunganya.

Sebagai seorang contoh seorang yang pada awalnya mempunyai prestasi kerja yang berupa karir menduduki posisi jabatan tertentu misalnya supervisor, kemudian melewati banyak situasi dan peluang yang terhampar selama menyusuri perjalanan kariernya dapat berbelok dan diantaranya yang melompat menduduki jabatan manajerial. Tetapi banyak pula yang tepat dijalur profesi supervisor, karena mengalami stagnasi dalam perkembangan karirnya, tentu saja hal ini perlu diketahui mengapa pegawai tersebut tidak dapat meningkatkan prestasinya.

Pengetahuan pegawai sangat berpengaruh pada prestasi kerja seseorang, pengetahuan pegawai antara lain terbagi menjadi beberapa jenis seperti pengetahuan umum, tekhnologi dan linkungan kerja apabila ketiga hal tersebut diatas dapat terpenuhi maka akan menghasilkan sebuah Prestasi kerja yang memuaskan.

Kemudian keterampilan pegawai sangat diharapkan bagi setiap oragnisasi karena keterampilan kerja merupakan salah satu hal utama yang harus dimiliki semua pegawai agar menghasilkan prestasi kerja yang baik.

Selain pengetahuan dan keterampilan, sikap pegawai juga sangat diharapkan bagi organisasi karena sikap merupakan hal penting demi terwujudnya prestasi kerja yang baik, dalam hal ini seluruh pegawai diharapakan memiliki sikap kerja yang baik, dan bersikap mencintai terhadap pekerjaannya masing masing.

Dalam pelayanan kesehatan yaitu pada pegawai Pos Pembinaan Terpadu (POSBINDU) Kabupaten Tabalong sangat diperlukan kompetensi pegawai yang terdiri dari pengetahuan yaitu yang mencakup latar belakang pendidikan pegawai dalam memberikan pelayanan kesehatan kepada masyarakat, keterampilan dari pegawai Pos Pembinaan Terpadu (POSBINDU) Kabupaten Tabalong sangat diperlukan mengingat pelayanan kesehatan perlu di lakukan oleh orang yang ahli dalam bidangnya keterampilan pegawai terus ditingkatkan agar pegawai menjadi lebih baik lagi dalam memberikan pelayanan kesehatan dengan tidak melakukan kesalahan sekecil apapun, selain pengetahuan dan keterampilan, sikap pegawai Pos Pembinaan Terpadu (POSBINDU) Kabupaten Tabalong sangat berpengaruh terhadap kinerja pegawai karena saat ini pelayanan yang kurang ramah di bidang kesehatan masih menjadi keluhan masyarakat untuk itu untuk menghilangkan pandangan tersebut diharapkan semua pegawai memiliki sikap yang baik dalam bekerja seperti ramah dan perhatian kepada masyarakat.

Selain Kompetensi, pegawai Pos Pembinaan Terpadu (POSBINDU) 
Kabupaten Tabalong perlu mendapatkan perhatian berupa motivasi atas apa yang telah dikerjakannya, motivasi diberikan yang berbentuk finansial maupun non finansial agar kinerjanya menjadi baik juga dan tidak menurun. Motivasi Kerja menjadi dasar utama bagi seseorang memasuki suatu organisasi adalah dalam rangka usaha orang yang bersangkutan memuaskan berbagai kebutuhannya. Oleh karena itu kunci keberhasilan seorang manajer/pimpinan dalam menggerakkan bawahannya terletak pada kemampuannya memahami teori Motivasi Kerja sehingga menjadi daya pendorong yang efektif dalam upaya peningkatan Koordinasi dalam suatu instansi pemerintahan.

Beberapa hasil penelitian sebelumnya yang meneliti tentang Motivasi Kerja antara lain penelitian yang dilakukan Bodur (2002:98) yang menemukan bahwa tingkat kepuasan seluruh staff pusat kesehatan masyarakat di Turki tergolong rendah disebabkan oleh kondisi kerja yang tidak nyaman, kecilnya peluang mengembangkan karir dan gaji yang terlalu rendah. Matthews (2006:77) menemukan bahwa tingkat kepuasan dipengaruhi oleh Motivasi Kerja (lingkungan kerja fisik/tempat kerja yang baik, system penggajian yang adil, pengharapan, peluang pengembangan karir, pekerjaan yang pantas).

Berdasarkan beberapa pengertian

Motivasi Kerja tersebut, maka dapat dikatakan bahwa Motivasi Kerja adalah sebagai energi untuk membangkitkan dorongan dari dalam diri karyawan yang berpengaruh, membangkitkan, mengarahkan, dan memelihara prilaku seseorang berkaitan dengan lingkungan kerja. Jadi Motivasi Kerja adalah dorongan dari dalam diri pegawai untuk memenuhi kebutuhan yang stimulasi berorientasi kepada tujuan individu dalam mencapai rasa puas, kemudian diimplementasikan kepada orang lain untuk memberikan pelayanan yang baik kepada masyarakat dalam hal ini pelayanan kesehatan kepada masyarakat di Kabupaten Tabalong.
Fenomena sata ini pada instansi pemerintahan lebih fokus diberikan sanksi - sanksi atau hukuman sebagai efek jera namun penghargaan atas pencapaian seorang pegawai sering terlupakan, penghargaan tidak harus berbentuk material bisa saja diberikan dengan pengakuan penghargaan oleh pimpinan yang diberikan kepada pegawai yang telah berprestasi, hal ini dilakukan agar pegawai merasa dihargai atas hasil kerja yang telah dicapainya.

Kinerja atau Prestasi kerja dapat menunjukkan seberapa besar kontribusi pegawai pada organisasi dalam mencapai standar kerja yang telah ditetapkan.

Standar kerja perlu dijadikan sebagai tolak ukur dalam mengadakan perbandingan antara apa yang telah dilakukan dengan apa yang diharapkan. Untuk mencapai tujuan organisasi tersebut maka pegawai dituntut untuk mampu mengendalikan diri dalam menghadapi timbulnya ketegangan yang terjadi dalam menjalankan setiap pekerjaan atau kegiatan di organisasi tersebut.

Objek dalam penelitian ini adalah Pos Pembinaan Terpadu (POSBINDU) Kabupaten Tabalong. Posbindu PTM merupakan peran serta masyarakat dalam melakukan kegiatan deteksi dini dan pemantauan faktor risiko PTM Utama yang dilaksanakan secara terpadu, rutin, dan periodik.

Faktor risiko penyakit tidak menular (PTM) meliputi merokok, konsumsi minuman beralkohol, pola makan tidak sehat, kurang aktifitas fisik, obesitas, stres, hipertensi, hiperglikemi, hiperkolesterol serta menindak lanjuti secara dini faktor risiko yang ditemukan melalui konseling kesehatan dan segera merujuk ke fasilitas pelayanan kesehatan dasar. Kelompok PTM Utama adalah diabetes melitus (DM), kanker, penyakit jantung dan pembuluh darah (PJPD), penyakit paru obstruktif kronis (PPOK), dan gangguan akibat kecelakaan dan tindak kekerasan. 
Berdasarkan uraian diatas maka peran Pegawai Pos Pembinaan Terpadu (POSBINDU) Kabupaten Tabalong sangat diperlukan kinerjanya sebagai perannya dalam usaha deteksi dini atas penyakit berbahaya yang saat ini marasa terjadi pada masyarakat dan kurang menjadi perhatian serius pada masyarakat khususnya pada kebiasaan pola hidup tidak sehat dari masyarakat seperti kebiasaan merokok yang masih menjadi masalah utama yang sangat sulit di hentikan masyarakat.

\begin{tabular}{llrr}
\multicolumn{2}{c}{ Berdasarkan pada } & penjelasan \\
tersebut diatas, maka & diperlukan \\
pengkajian yang & berkaitan dengan \\
"Pengaruh & Kompetensi & dan Motivasi \\
Terhadap Kinerja & Pegawai Pos \\
Pembinaan & Terpadu & (POSBINDU) \\
Kabupaten Tabalong &
\end{tabular}

\section{Studi Literatur}

\section{Pengertian Kompetensi}

Boulter, Dalziel dan Hill (1996) mendefinisikan "Kompetensi sebagai karakteristik dasar dari seseorang yang memungkinkan karyawan mengeluarkan kinerja superior dalam pekerjaannya". Kompetensi merupakan bagian kepribadian yang mendalam dan melekat pada seseorang dengan perilaku yang dapat diprediksi pada berbagai keadaan dan tugas pekerjaan. Prediksi siapa yang berkinerja baik dan kurang baik dapat diukur dari kriteria atau standar yang di gunakan.

Pengertian kompetensi adalah karakteristik yang mendasari seseorang berkaitan dengan efektivitas kinerja individu dalam pekerjaannya atau karakteristik dasar yang memiliki hubungan kasual atau sebagai sebab-akibat dengan kriteria yang dijadikan acuan, efektif atau berkinerja prima atau superior di tempat kerja atau pada situasi tertentu.

\section{Makna Kompetensi}

Menurut Spencer dalam Moeheriono (2009:4) kompetensi terletak pada bagian dalam setiap manusia dan selamanya ada pada kepribadian seseorang yang dapat memprediksikan tingkah laku dan performansi secara luas pada semua situasi dan tugas pekerjaan atau jobs task.

Adapun makna yang terkandung dari defenisi kompetensi ini adalah:

a. Karakteristik dasar (uderlying characteristic) kompetensi adalah bagian dari kepribadian yang mendalam dan melekat pada seseorang serta mempunyai perilaku yang dapat diprediksi pada berbagai keadaan tugas pekerjaan.

b. Hubungan kasual (causally related) berarti kompetensi dapat menyebabkan atau digunakan untuk memprediksikan kinerja seseorang, artinya jika mempunyai kompetensi yang tinggi, maka akan mempunyai kinerja yang tinggi pula (sebagai akibat).

c. Kriteria (criterian referenced) yang dijadikan sebagai acuan, bahwa kompetensi secara nyata akan memprediksi seseorang dapat bekerja dengan baik, harus terukur dan spesipik atau terstandar.

Memiliki SDM adalah keharusan bagi perusahaan. Mengelola SDM berdasarkan kompetensi diyakini bisa lebih menjamin keberhasilan mencapai tujuan. Sebagian besar perusahaan memakai kompetensi sebagai dasar dalam memilih orang, mengelola kinerja, pelatihan dan pengembangan serta pemberian kompensasi.

\section{Jenis Komptensi Sumber Daya Manusia \\ 1. Pengetahuan}

Pengetahuan adalah hasil dari tahu dan ini terjadi setelah orang melakukan penginderaan terhadap suatu objek tertentu, penginderaan terjadi melalui panca indera manusia, yakni indra penglihatan, pendengaran, penciuman, rasa dan raba. Pengetahuan merupakan faktor yang sangat penting dalam membentuk tindakan seseorang. Notoadmojo (2005:96). 
Menurut Gie (2007:21) pengetahuan adalah keseluruhan faktafakta, keterangan dan asas-asas yang diperoleh seseorang melalui belajar dan pengalaman. Boutler (2005:39) menyatakan bahwa pengetahuan adalah apa yang diketahui seseorang tentang suatu topik, dan suatu kemampuan yang diperoleh melalui pendidikan formal dan informal, adapun kemampuan pengetahuan terdiri dari :

1. Pengetahuan umum (general knowledge) suatu kemampuan yang secara garis besar saja (umum) dalam aktifitas kerjanya seperti : (mengerti komputer, menulis suratsurat / korespondensi)

2. Professional-Specific Knowledge, adalah kemampuan pengetahuan yang berhubungan dengan profesionalitas secara keseluruhan, seperti; kemampuan pengetahuan dalam legal framework (lawyer), atau prinsip-prinsip manajemen keuangan (accountant), dan proses manajemen data atau informasi (SIM).

Notoatmodjo

(2005:91)

berpendapat bahwa pengetahuan merupakan hasil dari tahu, dan ini terjadi setelah orang melakukan penginderaan terhadap suatu obyek tertentu. Penginderaan terjadi melalui pancaindra manusia, yaitu indera penglihatan, pendengaran, penciuman, rasa dan raba. Sebagian besar pengetahuan manusia diperoleh melalui mata dan telinga. Pengetahuan atau cognitive merupakan domaian yang sangat penting dalam membentuk tindakan seseorang. Pengetahuan yang tercakup dalam domain kognitif mempunyai 6 tingkatan, yaitu:

1. Tahu (know)

Tahu diartikan sebagai mengingat suatu materi yang telah dipelajari sebelumnya atau rangsangan yang telah diterima. Kata kerja untuk mengukur bahwa orang tahu tentang apa yang dipelajari antara lain menyebutkan, menguraikan, mendefinisikan, menyatakan, dan sebagainya.

2. Memahami (comprehension)

Memahami diartikan sebagai kemampuan untuk menjelaskan secara benar tentang obyek yang diketahui, dan dapat menginterprestasikan materi tersebut secara benar. Orang yang telah paham terhadap obyek atau materi harus dapat menjelaskan, menyebutkan contoh, menyimpulkan, meramalkan, dan sebagainya terhadap obyek yang dipelajari.

3. Aplikasi (application)

Aplikasi diartikan sebagai kemampuan untuk menggunakan materi yang telah dipelajari pada situasi atau kondisi sebenarnya. Aplikasi disini dapat diartikan sebagai aplikasi atau penggunaan hokum-hukum, rumus, metode, prinsip, dan sebagainnya dalam konteks atau situasi yang lain.

4. Analisis (analysis)

Analisis adalah kemampuan untuk menjabarkan materi atau suatu obyek ke dalam komponenkomponen, tetapi masih di dalam satu struktur organisasi, dan masih ada kaitannya satu sama lain. Kemampuan analisis ini dapat dilihat dari penggunaan kata kerja seperti dapat menggambarkan (membuat bagan), membedakan, memisahkan, mengelompokkan, dan sebagainya.

\section{Sintesis (synthesis)}

Sintesis menunjuk kepada suatu kemampuan untuk meletakkan atau menghubungkan bagian-bagian di dalam suatu bentuk keseluruhan yang baru. Dengan kata lain, dapat menyusun formulasi baru dari formulasi yang ada.

6. Evalusi (evaluation) 
Evaluasi ini berkaitan dengan kemampuan untuk melakukan justifikasi atau penilaian terhadap suatu materi atau obyek. Penilaian ini didasarkan pada kriteria yang telah ada.

Adapun beberapa pendapat menyatakan bahwa pengetahuan seseorang dapat dipengaruhi oleh beberapa faktor antara lain pendidikan, pelatihan, pekerjaan, umur dan masa kerja. Untuk lebih jelasnya beberapa faktor dapat diuraikan sebagai berikut:

1. Pendidikan

Pendidikan adalah segala sesuatu untuk membina kepribadian dan mengembangkan kemampuan manusia, jasmaniah, dan rohaniah yang berlangsung seumur hidup, baik didalam maupun di luar sekolah (Dwiyanti, 2005:201).

Pendidikan dapat mempengaruhi proses belajar, semakin tinggi pendidikan seseorang maka makin mudah orang tersebut untuk menerima informasi. Dengan pendidikan tinggi maka seseorang akan cenderung untuk mendapatkan informasi, baik dari orang lain maupun dari media massa. Informasi diperoleh dari berbagai sumber mempengaruhi tingkat pengetahuan seseorang. Jika seseorang mendapatkan banyak informasi , cenderung memiliki pengetahuan yang luas (Notoatmodjo, 2005:111).

2. Pelatihan

Pelatihan adalah bagian dari pendidikan yang menyangkut proses belajar untuk memperoleh dan meningkatkan ketrampilan di luar system pendidikan yang berlaku dalam waktu yang relatif singkat, dan dengan metode yang lebih mengutamakan praktek daripada teori. Pelatihan merupakan proses aplikasi terhadap peningkatan kecakapan seseorang (Dwiyanti, 2005:202).

3. Pekerjaan
Pekerjaan adalah sesuatu yang dilakukan untuk mencari nafkah. Adanya pekerjaan memerlukan banyak waktu dan tenaga untuk menyelesaikan berbagai jenis pekerjaan yang masing-masing dianggap penting dan memerlukan perhatiannya. Masyarakat yang sibuk memiliki sedikit waktu untuk memperoleh informasi (Notoadmodjo, 2005:113).

4. Umur

Semakin lanjut umur seseorang, kemungkinan untuk menyelidiki sendiri suatu hal lebih banyak, maka hasil tahunya lebih banyak pula, bahkan lebih mendalam serta kepuasanyapun lebih besar.

5. Masa kerja

Masa kerja adalah lamanya waktu seseorang bekerja terhitung mulai masuk kerja hingga waktu berhenti bekerja. Masa kerja dapat mempengaruhi pengetahuan. Masa kerja yang lama ditambah dengan praktek yang terus menerus akan dapat menambah serta meningkatkan kecakapan seseorang, pekerjaan akan makin bermutu dan makin cepat selesai. Dengan demikian, pengetahuan adalah merupakan hasil tahu dari keseluruhan fakta-fakta, keterangan dan asas-asas yang diperoleh seseorang melalui belajar dan pengalaman.

\section{Keterampilan (skill)}

Menurut Irianto (2008:76)

Ketrampilan merupakan kombinasi dari beberapa kemampuan kerja fisik dan non fisik dalam kaitannya dengan aplikasi perolehan pengetahuan baru. Selanjutnya dikemukakan bahwa ketrampilan selain sebagai keahlian kasat mata, makna skill juga mengacu pada persoalan mental, manual, motorik, perceptual, dan bahkan social ability seseorang.

Martoyo (2007:23) membagi ketrampilan (skill) menjadi 3 golongan yaitu : 
1. Technical Skill (ketrampilan teknis), merupakan jenis keahlian utama yang harus dimiliki oleh para karyawan.

2. Human Skill (ketrampilan kemanusiaan), merupakan jenis keahlian yang harus dimiliki oleh mereka yang akan memangku jabatan pimpinan, sebagai figur yang harus mampu mengkoordinir aktifitas-aktifitas utama dalam rangka mencapai tujuan-tujuan organisasi.

3. Conseptual Skill (ketrampilan konseptual), merupakan jenis keahlian yang harus dimiliki oleh mereka yang akan memangku jabatan pimpinan, sebagai figur yang harus mampu mengkoordinir aktifitas-aktifitas utama dalam organisasi dalam rangka mencapai tujuan-tujuan organisasi.

Menurut (Byham, 2007:5-19)

Analisi kompetensi lebih didasarkan pada Skill, knowledge, ability atau atau dengan kata lain disebut : Competency Skill, knowledge, ability-based Human Resources Deveopment.

Beberapa variabel Competency Skill and knowledge yang sangat diperlukan sebagai seorang karyawan sebagai berikut :

1. Kompetensi ketrampilan (skill) merupakan suatu kemampuan dengan tugas yang dimiliki dan dipergunakan dalam menghadapi tugas yang bersifat teknis atau non teknis

Kompetensi skill yang bersifa teknis yaitu, kemampuan bertindak, menggunakan atau mendemonstrasikan ketrampilan seperti :
a. Using to equipment and tools, yaitu kemampuan menggunakan atau mengoperasikan sarana- prasarana perlengkapan dan peralatan yang ada dikantor baik peralatan yang lama maupun yang baru oleh seluruh

karyawan dalam suatu perusahaan atau organisasi, misalnya kemampuan membuat drafting, installing, drawing and surveying.

b. Professional expertise, kemampuan mengaplikasi ktrampilan profesi yang dimilikinya secara teknis dalam menggunakan sumbersumber daya perusahaan atau organisasi, seperti : kemampuan menerapkan ketrampilannya untuk meningkatkan kinerja dan mengatasi masalah-masalah yang terjadi. Kemampuan menerjemahkan jargonjargon/istilah-istilah teknis kedalam bahasa yang umum. Kemampuan menghubungkan antara ketrampilannya dengan masalah-masalah.

c. Working with Computer and Information Technology, kemampuan dalam melaksanakan suatu pekerjaan atau tugas-tugas dengan menggunakan atau mengoperasional tehnologi komputer maupun tehnologi informasi, untuk menjamin peningkatan kerja dan efisiensi kerja.

Kompetensi yang harus dimiliki oleh seluruh karyawan atau aparatur bersifat non teknis seperti :

a. Performing office tasks, yaitu kemampuan melaksanakan suatu pekerjaan-pekerjaan kantor dengan efisiensi yang tinggi, misalnya : mengklasifikasi, menyortir, melakukan korespondensi dan mencatat data, memasukan dan memverifikasi data dengan akurat serta mengakses informasi dengan cepat, tepat dan akurat. 
b. Clients service, yaitu kemampuan memberikan pelayanan kepada klien atau konsumen/masyarakat, misalnya : mencermati kebutuhan-kebutuhan dan harapan klien, konsumen atau masyarakat, memberikan kesempatan kepada klien mengutarakan kebutuhannya serta memahami adanya perubahan kebutuhan atau harapan klien, konsumen.

c. Business awareness, kemampuan menggunakan informasi-informasi keuangan, membuat keputusan bisnis, mengatur pendapatan, kelihaian berbisnis.

d. Working with Data/numbers, kemampuan keahlian atau ketrampilan dalam bekerja dengan mampu mengerti dan memahami antara data-data atau angka yang ada dengan konsep-konsep yang digunakan.

Ketrampilan merupakan kombinasi dari beberapa kemampuan kerja fisik dan non fisik dalam kaitannya dengan aplikasi perolehan pengetahuan baru. Ketrampilan bisa mencakup ketrampilan teknis, kemanusiaan, dan konseptual.

\section{Sikap (attitude)}

Pengertian sikap sebenarnya tidak sesederhana persepsi umum yakni suatu sistem nilai tertentu pada kehidupan seseorang atau sekelompok orang, namun menyangkut hal-hal yang lebih mendasar dan bersifat komplek pada seseorang. Beberapa definisi sikap dari beberapa ahli, menurut Thurstone dan Osgood dalam Azwar (2005 : 3) sikap adalah suatu bentuk evaluasi atau reaksi perasaan. Sikap seseorang terhadap obyek adalah perasaan mendukung atau memihak (favorabel) ataupun tidak mendukung (tidak favorabel) terhadap obyek tersebut.

Allport (2008:3) menyatakan sikap merupakan semacam kesiapan bereaksi terhadap suatu obyek dengan cara-cara tertentu. Agaknya tidak keliru bila kita menafsirkan kesiapan dalam definisi ini sebagai kecenderungan potensial untuk bereaksi apabila individu dihadapkan pada suatu stimulus yang menghendaki respon.

Sutherland dan Wood Worth (2008 :176) mengartikan sikap sebagai predeposisi untuk bertindak atau kecenderungan untuk mengadakan respon dengan cara-cara yang khas terhadap suatu obyek yang berupa orang atau situasi tertentu.

Gerungan

menerjemahkan attitude dengan katakata sikap terhadap obyek tertentu yang dapat merupakan sikap pandangan atau sikap perasaan, namun demikian sikap tersebut disertai pula oleh kecenderungan untuk bertindak sesuai sikap terhadap obyek. Jadi attitude lebih tepat diterjemahkan sebagai sikap atau kesediaan bereaksi terhadap suatu situasi.

Sikap oleh LaPierre dalam Azwar (2005:112) dikatakan sebagai suatu pola perilaku, tendensi atau kesiapan antisipatif, predisposisi untuk menyesuaikan diri dalam situasi sosial, atau secara sederhana sikap adalah respons terhadap suatu stimulus yang telah terkondisikan.

Sedangkan Secord dan

Backman dalam Azwar (2005:121) mendefinisikan sikap sebagai keteraturan tertentu dalam hal perasaan (afeksi), pemikiran (kognisi), dan predisposisi tindakan (konasi) seseorang terhadap suatu aspek lingkungan sekitarnya.

Dari definisi-definisi tersebut di atas dapat ditarik kesimpulan bahwa sikap merupakan suatu bentuk evaluasi perasaan dan kecenderungan potensial untuk bereaksi yang merupakan hasil 
interaksi antara komponen kognitif, afektif, dan konatif yang saling beraksi dalam memahami, merasakan dan berperilaku terhadap suatu obyek.

Beberapa ahli mempunyai pandangan yang berbeda-beda dalam membahas komponen yang membentuk struktur sikap. Thurstone memandang bahwa komponen afektif yang membentuk struktur sikap. Allport mengatakan bahwa komponen kognitif merupakan penyebab terjadinya sikap percaya terhadap suatu obyek (Azwar, $2005: 3$ ).

Sikap terhadap obyek, gagasan atau orang tertentu merupakan orientasi yang bersifat menetap dengan komponen kognitif, afektif dan perilaku (konatif).

Komponen kognitif terdiri dari seluruh kognisi yang dimiliki seseorang mengenai obyek sikap tertentu, yaitu fakta, pengetahuan dan keyakinan tentang obyek.

Komponen afektif terdiri dari seluruh perasaan atau emosi seseorang terhadap obyek, terutama penilaian. komponen perilaku terdiri dari kesiapan seseorang untuk bereaksi terhadap obyek sikap (Sears, 2008 : 138).

Gerungan (2002 : 13) menyatakan bahwa komponen kognitif adalah pandangan, komponen afektif adalah perasaan, sedangkan komponen perilaku adalah kecenderungan untuk bertindak sesuai dengan sikap terhadap obyek. Walgito (2004 : 109) berpendapat bahwa pengertian sikap mengandung komponen kognitif (beliefs), komponen afektif (feeling), dan komponen konatif (behaviour tendencies).

Dari beberapa pendapat di atas, Azwar (2005:191) menyimpulkan bahwa faktor-faktor yang mempengaruhi pembentukan sikap adalah pengalaman pribadi, kebudayaan, orang lain yang dianggap penting, media massa, institusi atau lembaga pendidikan dan lembaga agama, serta faktor emosi dalam diri individu.

Dari uraian di atas dapat disimpulkan bahwa komponenkomponen yang membentuk struktur sikap ada tiga yaitu :

a. Komponen kognitif, berupa pengetahuan, kepercayaan, pandangan atau pikiran yang didasarkan pada informasi dan bagaimana orang mempersepsikan obyek sikap tersebut.

b. Komponen afektif, menunjukkan dimensi emosional dari sikap. Komponen ini berhubungan dengan perasaan yaitu perasaan senang (positif) atau perasaan tidak senang (negatif). Komponen ini menunjukkan arah sikap.

c. Komponen konatif atau komponen perilaku (action component), melibatkan predisposisi untuk bertindak, berhubungan dengan kecenderungan untuk bertindak terhadap obyek sikap.

\section{Pengertian Motivasi}

Motivasi membicarakan tentang bagaimana cara mendorong semangat kerja sesorang, agar mau bekerja dengan memberikan secara optimal kemampuan dan keahliannya guna mencapai tujuan organisasi. Motivasi adalah keinginan yang terdapat pada seorang individu yang merangsang untuk melakukan tindakan (Winardi, 2000:312). Sedangkan pendapat lain mengatakan bahwa motivasi adalah suatu keahlian, dalam mengarahkan pegawai dan organisasi agar mau bekerj secara berhasil, sehingga keinginan para pegawai dan tujuan organisasi sekaligus tercapai (Flippo, 2000). Seperti telah dikutip di depan bahwa pengertian motivasi, menurut berelson dan steiner dalam Sunyoto (2012: 11) adalah suatu usaha sadar untuk mempengaruhi perilaku seseorang supaya mengarah tercapainya tujuan organisasi.

Selain pendapat diatas ada beberapa pendapat yang memberikan pengertian yang sama atau hamper sama yaitu : “ 
menurut Casio dalam Hasibuan (2011:95) keinginan seseorang untuk memuaskan kebutuhannya, missal : rasa lapar, haus, dan dahaga".

\section{Indikator Motivasi}

Berikut teori motivasi "dua faktor" menurut Herzberg yang dapat dijadikan sebagai acuan guna mengukur motivasi yang dikutip oleh Siagian (2012:164) adalah sebagai berikut :

\section{Tabel 1 Teori Motivasi "Dua Faktor"} Menurut Herzberg yang dikutip Sunyoto (2012:11) motivasi adalah suatu kekuatan yang dihasilkan dari

Pada umumnya para ahli meninjau kinerja dari efesiensi dan semangat kerja. Baik mengenai cara - cara untuk member Etos Kerja manusia dalam mencapai prestasi yang tinggi, faktor faktor yang mempengaruhi kinerja maupun penelitian untuk meniadakan pengaruh negatife dari kinerja tenaga kerja.

Kinerja adalah suatu hasil kerja yang dicapai seseorang dalam melaksanakan menyelesaikan pekerjaan yang dibebankan kepadanya. Sedangkan faktor prestasi kerja yang akan diteliti meliputi Etos Kerja kerja dan kepuasan kerja heidjrachman, Suad Hasan

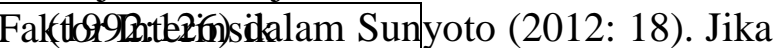
Kebijaksanaan dan Administrasi Supervisi

Gaji / Upah

Hubungan antar pribadi Kondisi Kerja Sumber : Siagian (2012:164)

Herzberg memandang bahwa kepuasan kerja berasal dari keberadaan motivator intrinsik dan bahwa ketidakpuasan kerja berasal dari ketidakberadaan faktor-faktor ekstrinsik.

Dengan demikian seseorang yang terdorong secara intrinsik akan menyenangi pekerjaannya, memungkinkan menggunakan kreatifitas dan inovasi dan tidak perlu diawasi dengan ketat. Kepuasan disini tidak dikaitkan dengan perolehan hal - hal yang bersifat materi. Sebaliknya, mereka yang terdorong oleh faktor - faktor ekstrinsik cenderung melihat kepada apa yang diberikan oleh organisasi kepada mereka dan kinerjanya diarahkan kepada perolehan hal - hal yang diinginkannya dari organisasi. Menurut herzberg faktor ekstrinsik tidak akan mendorong para karyawan untuk berforma baik, akan tetapi jika faktor - faktor ini dianggap tidak memuaskan dalam berbagai hal seperti gaji tidak memadai, kondisi kerja tidak menyenangkan, hal tersebut dapat menjadi sumber ketidakpuasan potensial.

\section{Kinerja Pegawai} Keberhasilarang tenaga kerja mempunyai perasaan PengakuanbePereghtarigamaka ia harus mempunyai cara Pekerjaan intskdndirimengukur kemajuan yang Tanggung glikaldkannya. Mereka menginginkan Pengembatigapan balik meskipun mereka tidak hukuman untuk kegagalan mereka.

\section{Pengukuran Kinerja dan Indikator Kinerja Pegawai \\ Untuk dapat mengevaluasi} karyawan secara objektif dan akurat seorang penyelia harus mampu mengukur tingkat kinerja mereka. Pengukuran kinerja dapat berpungsi sebagai target atau sasaran sebagai aktivitas pengukuran standard an sebagai informasi yang dapat digunakan para karyawan, dalam mengarahkan usaha - usaha mereka melalui serangkaian prioritas tertentu. Menurut Edwin Flippo dalam Sunyoto (2012:22), prestasi kerja seseorang dapat diukur melalui :

1. Mutu kerja, berkaitan dengan ketepatan waktu, keterampilan dan keperibadian dalam melakukan pekerjaan.

2. Kualitas kerja, berkaitan dengan pemberian tugas - tugas tambahan yang diberikan oleh atasan kepada bawahannya.

3. Ketangguhan, berkaitan dengan tingkat kehadiran, pemberian waktu libur dan jadwal keterlambatan hadir di tempat kerja. mendapat hadiah untuk pekerjaan dan 
4. Sikap, merupakan sikap yang ada pada karyawan yang menunjukkan seberapa jauh sikap tanggung jawab mereka terhadap sesama teman, sengan atasan dan seberapa jauh tingkat kerjasama dalam menyelesaikan pekerjaan.

Menurut Keban (2004:109) dalam Pasolong (2012:184) pengukuran kinerja pegawai penting dilakukan oleh instansi pelayanan publik.Dengan mengetahui kelemahan dan kelebihan, hambatan dan dorongan, atau berbagai faktor sukses bagi kinerja pegawai serta institusi maka terbukalah jalan menuju profesionalisasi, yaitu memperbaiki kesalahan-kesalahan yang dilakukan selama ini.

Terdapat berbagai teori mengenai indikator kinerja pegawai. Salah satunya indikator kinerja pegawai Fadel (2012:195) mengemukakan beberapa indikator yang digunakan untuk mengukur kinerja pegawai yaitu:

a) Pemahaman atas tupoksi

Dalam menjalankan tupoksi, bawahan harus terlebih dahulu paham tentang tugas pokok dan fungsi masingmasing serta mengerjakan tugas sesuai dengan apa yang menjadi tanggung jawabnya.

b) Inovasi

Memiliki inovasi yang positif dan menyampaikan pada atasan serta mendiskusikanya pada rekan kerja tentang pekerjaan.

c) Kecepatan kerja

Dalam menjalankan tugas kecepatan kerja harus diperhatikan dengan menggunakan mengikuti metode kerja yang ada.

d) Keakuratan kerja

Tidak hanya cepat, namun dalam menyelesaikan tugas karyawan juga harus disiplin dalam mengerjakan tugas dengan teliti dalam bekerja dan melakukan pengecekan ulang

e) Kerjasama

Kemampuan dalam bekerjasama dengan rekan kerja lainya seperti bisa menerima dan menghargai pendapat orang lain.

\section{Penelitian Terdahulu}

Sebagai bahan pertimbangan dalam penelitian Pengaruh Kompetensi Terhadap Kinerja, diantaranya dikemukakan oleh :

1. Devi Rusvitawati. 2016. Pengaruh Kompetensi Terhadap Kinerja Karyawan Rumah Sakit Sari Mulia Banjarmasin. Rumah sakit harus dapat memberikan layanan yang memenuhi harapan pasien jadi mereka tertarik memanfaatkan layanan ini. Memperbaiki Kualitas layanan harus disertai dengan peningkatan kinerja para karyawan. Prestasi kerja karyawan terdiri dari orang-orang terstandarisasi kualitas sumber daya dan yang terkait dengan kompetensi. Penelitian ini bertujuan untuk mengidentifikasi dan untuk menganalisis pengaruh pencapaian dan kompetensi pada tindakan, bantuan dan kompetensi layanan manusia, dampak dan pengaruh kompetensi, manajerial kompetensi, kompetensi kognitif, dan kompetensi efektivitas pribadi pada kinerja karyawan di Rumah Sakit Sari Mulia Banjarmasin. Ada 310 karyawan di Rumah Sakit Sari Mulia Banjarmasin sebagai populasi penelitian. Sampel probabilitas dengan teknik pengambilan sampel proporsional digunakan sebagai teknik pengambilan sampel. Data dikumpulkan dengan membagikan kuesioner kepada sampel 173 karyawan di Rumah Sakit Sari Mulia Banjarmasin. Telah dikumpulkan Data dianalisis menggunakan regresi berganda. Berdasarkan temuan Penelitian, ditemukan bahwa setiap variabel kompetensi mempengaruhi karyawan prestasi kerja di Rumah Sakit Sari Mulia Banjarmasin.

2. Sultan dan Sevanus Thane. 2016. Pengaruh Kompetensi, Motivasi, Beban Kerja Perawat Pelaksansa Terhadap Kinerja Perawat Diruang 
Rawat Inap Rumah Sakit Umum Daerah Jayapura. Hasil penelitian menunjukkan bahwa Kompetensi (X1) Pengaruh kompetensi terhadap kinerja berdasarkan tabel hasil uji t (parsial) dapat diketahui bahwa perhitungan SPSS diperoleh t hitung sebesar 4.348 dengan nilai probabilitas (nilai sig) 0.000. Nilai probabilitas tersebut lebih kecil dari alpha (5\%). Dengan demikian dapat disimpulkan bahwa variabel kompetensi berpengaruh terhadap kinerja. Berdasarkan analisis regresi linier berganda, maka dapat dijelaskan bahwa nilai koefisien kompetensi sebesar 0,216. Hal ini mengandung arti bahwa setiap kenaikan kepuasan kerja satu satuan maka variabel kinerja akan naik sebesar 0,216 dengan asumsi bahwa variabel bebas yang lain dari regresi adalah tetap. Motivasi (X2) Pengaruh motivasi kerja terhadap kinerja berdasarkan tabel hasil uji t (parsial) dapat diketahui bahwa perhitungan SPSS diperoleh t hitung sebesar 9.279 dengan nilai probabilitas (nilai sig) 0.000 . Nilai probabilitas tersebut lebih kecil dari alpha (5\%). Dengan demikian dapat disimpulkan bahwa variabel motivasi berpengaruh terhadap kinerja perawat. Berdasarkan analisis regresi linier berganda, maka dapat dijelaskan bahwa nilai koefisien motivasi sebesar 0,511. Hal ini mengandung arti bahwa setiap kenaikan motivasi kerja satu satuan maka variabel kinerja akan naik sebesar 0,511 dengan asumsi bahwa variabel bebas yang lain dari regresi adalah tetap. Sedangkan Beban kerja perawat pelaksana (X3) menunjukkan bahwa beban kerja perawat tidak berpengaruh terhadap kinerja. Tidak Pengaruh beban kerja perawat terhadap kinerja berdasarkan tabel hasil uji t (parsial), dapat diketahui bahwa perhitungan SPSS diperoleh $\mathrm{t}$ hitung sebesar 601 dengan nilai probabilitas (nilai tidak sig) 0.549 . Nilai probabilitas tersebut lebih besar dari alpa (5\%). Dengan demikian, dapat disimpulkan bahwa variabel beban kerja perawat tidak berpengaruh terhadap kinerja. Berdasarkan analisis regresi linier berganda, maka dapat dijelaskan bahwa nilai koefisien beban kerja perawat pelaksana adalah sebesar 0,034 . Hal ini mengandung arti bahwa setiap kenaikan beban kerja perawat satu satuan maka variabel kinerja akan naik sebesar 0,034 dengan asumsi bahwa variabel bebas yang lain dari regresi adalah tetap.

3. Revi Rizki Irawan. 2016 . Pengaruh Kompetensi Pegawai Dan Motivasi Kerja Terhadap Kinerja Perawat Rumah Sakit PTPN VIII Subang. Kinerja perawat merupakan aspek penting dalam rumah sakit, karena hal inilah yang akan menentukan maju atau mundurnya kinerja rumah sakit, kinerja rumah sakit sangat ditentukan oleh kualitas sumber daya manusia khususnya perawat. Melalui peningkatan kinerja perawat, maka efektivitas dan produktivitas rumah sakit pun akan meningkat. Untuk meningkatkan kinerja perawat dibutuhkan kompetensi yang baik serta meningkatkan motivasi perawat agar terdorong untuk kerja secara optimal. Penelitian ini bertujuan untuk mengetahui bagaimana kompetensi dan motivasi kerja terhadap kinerja perawat di Rumah Sakit PTPN VIII Subang. Metode penelitian yang digunakan dalam penelitian ini yaitu metode deskriptif dan verifikatif. Metode analisis data yang digunakan adalah analisis kuantitatif yaitu melalui analisis regresi berganda dan diproses dengan menggunakan software SPSS 20. Hasil penelitian ini menunjukan bahwa secara bersamasama kompetensi dan motivasi kerja berpengaruh terhadap kinerja perawat, dimana kompetensi dan motivasi kerja memberikan pengaruh sebesar $65,4 \%$ terhadap kinerja perawat. Demikian juga secara parsial baik kompetensi berpengaruh sebesar $41,2 \%$ maupun 
motivasi kerja berpengaruh sebesar 24,2 dan berpengaruh signifikan terhadap kinerja perawat. Kata kunci : Kompetensi, Motivasi Kerja dan Kinerja.

\section{Motode Penelitian \\ Lokasi Penelitian}

J1. Jaksa Agung Suprapto, Tanjung, Agung, Tanjung, Kabupaten Tabalong, Kalimantan Selatan 71513.

\section{Populasi dan Sampel}

Populasi

Menurut Sugiyono,

Populasi adalah wilayah generalisasi yang terdiri atas obyek/subyek yang mempunyai kualitas dan karakteristik tertentu yang ditetapkan untuk dipelajari dan kemudian ditarik kesimpulannya. Populasi dalam penelitian ini adalah seluruh Pegawai PNS dan Non PNS Pos Pembinaan Terpadu (POSBINDU) Kabupaten Tabalong yang berjumlah 80 (delapan puluh) orang.

Sampel

Sugiono (2012:89) Sampling jenuh adalah teknik penentuan sampel dimana semua anggota populasi digunakan sebagai sampel. Hal ini sering digunakan bila jumlah populasi relatif kecil.

Berdasarkan uraian diatas sampel yang digunakan dalam penelitian ini adalah sampel sensus dikarenakan kecilnya jumlah populasi, sehingga seluruh objek dalam populasi dijadikan sampel yaitu sebanyak 80 (delapan puluh) orang pegawai PNS dan Non PNS Pos Pembinaan Terpadu (POSBINDU) Kabupaten Tabalong. Dengan menggunakan sampel sensus.

\section{Teknik Analisis Data}

1. Intrumen Penelitian

Pengukuran variabel dalam penelitian ini menggunakan skala likert. Skala likert digunakan untuk mengukur sikap, pendapat, dan persepsi seseorang atau sekelompok orang tentang fenomena sosial.
Skala ini meminta responden menunjukan tingkat persetujuan atau ketidaksetujuannya terhadap serangkaian pertanyaan tentang suatu objek (Sugiyono, 2012).

Alat ukur yang digunakan adalah kuesioner yang akan diuji validitas dan reliabilitasnya, kinerja akan diukur dari pengaruh Kompetensi Pengetahuan, Kompetensi Keterampilan dan Kompetensi Sikap. Untuk masingmasing responden mempunyai 5 alternatif jawaban (Skala Likert). Masing-masing prioritas dari kelima point tersebut, yaitu:

1. Sangat setuju (SS) diberi nilai 5

2. Setuju (S) diberi nilai 4

3. Netral $(\mathrm{N})$ diberi nilai 3

4. Tidak setuju (TS) diberi nilai 2

5. Sangat tidak setuju (STS) diberi nilai 1

2. Uji Kuisioner

Untuk dapat dinyatakan bahwa hasil kuesioner yang disebarkan kepada responden dapat membuktikan bahwa jawaban responden adalah baik dan dapat dipercaya dari jawaban dari responden yang nantinya dipergunakan untuk dijadikan alat pembuktian hipotesa maka diperlukan uji sebagai berikut:

A. Uji Validitas

Uji validitas adalah untuk mengetahui tingkat kevalidan dari instrumen kuesioner yang digunakan dalam mengumpulkan data. Uji validitas ini dilakukan untuk mengetahui apakah item-item yang tersaji dalam kuesioner benar-benar mampu mengungkapkan dengan pasti apa yang diteliti.

Cara yang digunakan adalah dengan Analisa Item, dimana setiap nilai yang ada pada setiap butir pertanyaan dikorelasikan dengan nilai total seluruh butir pertanyaan untuk suatu variabel dengan 
menggunakan rumus Korelasi Product Moment (Sugiyono 2012:73).

Lebih lanjut, Sugiyono menyatakan bahwa biasanya syarat minimum untuk dianggap memenuhi syarat adalah kalau $r \geq$ 0,3 . Jadi apabila korelasi antara butir dengan skor total kurang dari 0,3 maka butir dalam instrumen tersebut dinyatakan tidak valid.

Uji validitas dengan menggunakan korelasi Product Moment dengan formulasi :

$$
r_{x y}=\frac{\Sigma x y}{\left(\Sigma x^{2}\right)\left(\Sigma y^{2}\right)}
$$

B. Uji Reliabilititas

Uji reliabilitas dimaksudkan untuk mengetahui adanya konsistensi alat ukur dalam penggunaannya, atau dengan kata lain alat ukur tersebut mempunyai hasil yang konsisten apabila digunakan berkali-kali pada waktu yang berbeda. Untuk uji reliabilitas ini digunakan Teknik Alpha Cronbach, dimana suatu instrumen dapat dikatakan handal (reliabel) apabila memiliki koefisien keandalan atau alpha sebesar 0,6 atau lebih (Arikunto 2012). Adapun formula dari alpha cronbach adalah sebagai berikut :

$$
\mathrm{r}_{11}=\left(\frac{\mathrm{k}}{\mathrm{k}-1}\right)\left(1-\frac{\sum \sigma_{\mathrm{b}}^{2}}{\sigma_{\mathrm{t}}^{2}}\right)
$$

Dimana :

$\mathrm{R}_{11}=$ reliabilitas instrumen

$\mathrm{K}=$ banyaknya butir pertanyaan atau banyaknya soal

$\sigma_{\mathrm{b}}{ }^{2} \quad=$ jumlah varians butir

$\sigma_{\mathrm{t}}^{2}=$ varians total (Arikunto, 2012)

Taraf signifikan digunakan $5 \%$. Jika $r$ hitung ( $r$ alpha) > $r$ tabel, maka instrumen tersebut dinyatakan reliabel. Sebaliknya jika $r$ alpha positif dan $\mathrm{r}$ alpha $<\mathrm{r}$ tabel, maka butir atau variabel tersebut tidak reliabel. Sugiyono (2012) menyebutkan bila $\mathrm{r}$ hitung ( $\mathrm{r}$ alpha) $>0,600$, maka instrumen tersebut dinyatakan reliabel. Arikunto (2012), tingkat reliabelitas instrumen bisa dilihat dari $r$ hitung ( $r$ alpha) dengan kriteria seperti pada tabel 1:

Tabel 1 Kriteria untuk $\mathrm{r}$ hitung ( $\mathrm{r}$ alpha)

\begin{tabular}{|c|c|}
\hline$r$ hitung $(r$ alpha $)$ & Kriteria \\
\hline $0,800-1,00$ & sangat tinggi \\
\hline $0,600-0,799$ & tinggi \\
\hline $0,400-0,599$ & cukup \\
\hline $0,200-0,399$ & rendah \\
\hline$<0,200$ & sangat rendah \\
\hline
\end{tabular}

Sumber : Arikunto (2012).

C. Uji Asumsi Klasik

Untuk memastikan apakah variabel-variabel penelitian dapat dianalisis dengan menggunakan Regresi Linier Berganda atau tidak, maka diperlukan suatu uji asumsi klasik sebagai persyaratan analisis regresi berganda. Variabel-variabel tersebut harus memenuhi syaratsyarat sebagai berikut:

1. Uji Multikolinieritas

Uji multikolinieritas ini digunakan untuk mengetahui ada tidaknya korelasi antara variabel independen. Jika terjadi korelasi, maka dinamakan terdapat problem multikolinieritas. Untuk mengetahui ada tidaknya multikolinieritas antar variabel, dapat dilihat dari Variable Inflation Factor (VIF) dari masing-masing variabel bebas terhadap variabel terikat. Menurut Santoso (2005: 357), jika nilai VIF tidak lebih besar dari 5 maka dalam model tidak terdapat multikolinieritas.

2. Uji Heteroskedastisitas

Uji heteroskedastisitas bertujuan untuk menguji apakah dalam sebuah model regresi terjadi ketidaksamaan varian dari residual dari suatu pengamatan lainnya. Jika varian dari pengamatan lainnya tetap, maka 
disebut homoskedastisitas. Sedangkan apabila variannya berbeda dari satu pengamatan ke pengamatan lainnya disebut dengan gejala heteroskedastisitas. Untuk mengetahui ada atau tidaknya gejala heteroskedastisitas adalah dengan melihat ada tidaknya pola tertentu pada grafik scatter plot. Apabila tidak ada pola yang jelas atau pola tertentu serta titik menyebar di atas dan di bawah angka 0 pada sumbu $Y$, maka tidak terjadi heteroskedastisitas.

3. Uji Normalitas

Uji Normalitas dilakukan dengan tujuan untuk mengetahui apakah dalam sebuah model regresi baik itu variabel terikat maupun variabel bebas secara terpisah atau secara bersamaan keduanya mempunyai distribusi normal atau tidak. Deteksi normalitas dilakukan dengan melihat penyebaran data (titik) pada sumbu diagonal dari grafik. Dasar pengambilan keputusan yang digunakan:

a) Jika data menyebar di sekitar garis diagonal dan mengikuti arah garis diagonal, maka model regresi memenuhi asumsi normalitas.

b). Jika data menyebar jauh dari garis diagonal, maka model regresi tidak memenuhi asumsi normalitas (Santoso, 2005:214).

D. Analisis Regresi Berganda.

Untuk mengetahui pengaruh variabel bebas terhadap variabel terikatnya menurut Anwar (2012:309) dengan bantuan SPSS Versi 21.0 digunakan rumus analisis regresi linier berganda sebagai berikut:

$\mathrm{y}=\mathrm{a}+\mathrm{b}_{1} \mathrm{x}_{1}+\mathrm{b}_{2} \mathrm{x}_{2}+\mathrm{e}$ dimana :

\begin{tabular}{|c|c|c|}
\hline $\begin{array}{l}\text { y } \\
\text { variabe }\end{array}$ & $\begin{array}{l}= \\
\text { ja) }\end{array}$ & dependent \\
\hline $\mathrm{a}$ & $=$ & konstata \\
\hline $\begin{array}{l}\mathrm{b}_{1}, \mathrm{~b}_{2}, \\
\text { regresi }\end{array}$ & $=$ & koefisien \\
\hline $\begin{array}{l}\mathrm{n} \\
\text { sampel }\end{array}$ & $=$ & banyaknya \\
\hline $\mathrm{X}_{1}$ & & $\begin{array}{l}\text { independent } \\
\text { abel } \\
\text { apetensi }\end{array}$ \\
\hline$X_{2}$ & & $\begin{array}{l}\text { independent } \\
\text { abel Motivasi }\end{array}$ \\
\hline
\end{tabular}

E. Pengujian Hipotesis

1. Uji Hipotesis I (Uji t)

Untuk menguji kebenaran hipotesis kedua langkah pertama yang dilakukan adalah pengujian secara parsial melalui uji $t$. Adapun rumusan hipotesis dengan menggunakan $\mathrm{Uji} \quad \mathrm{t}$ adalah sebagai berikut:

$\mathrm{H}_{0}: \quad \mathrm{b}_{1}=\mathrm{b}_{2}=\mathrm{b}_{3}=\mathrm{b}_{4}=0$ Artinya variasi variabel bebas dapat menerangkan variabel tidak bebas (variabel terikat) dan terdapat pengaruh diantara kedua variabel yang diuji

$\mathrm{H}_{\mathrm{a}}: \quad \mathrm{b}_{1} \neq \mathrm{b}_{2} \neq \mathrm{b}_{3} \neq \mathrm{b}_{4} \neq$ 0

Artinya variasi variabel bebas tidak dapat menerangkan variabel tidak bebas (variabel terikat) dan terdapat pengaruh antara dua variabel yang diuji.

Pengujian dilakukan melalui uji $\mathrm{t}$ dengan membandingkan $t_{\text {hitung }}$ $\left(t_{h}\right)$ dengan $t_{\text {tabel }}\left(t_{t}\right)$ pada $\alpha 0,05$. Apabila hasil perhitungan menunjukkan:

a. $t_{h} \geq t_{t}$ maka $H_{0}$ ditolak dan $\mathrm{H}_{\mathrm{a}}$ diterima

Artinya variasi variabel bebas dapat menerangkan variabel tidak bebas (variabel terikat) dan terdapat pengaruh diantara kedua variabel yang diuji.

b. $t_{\mathrm{h}}<\mathrm{t}_{\mathrm{t}}$ maka $\mathrm{H}_{0}$ diterima dan $\mathrm{H}_{\mathrm{a}}$ ditolak 
Artinya variasi variabel bebas tidak dapat menerangkan variabel tidak bebas (variabel terikat) dan terdapat pengaruh antara dua variabel yang diuji.

2. Uji Hipotesis II (Uji F)

Untuk menguji kebenaran hipotesis pertama digunakan uji $\mathrm{F}$ yaitu untuk menguji keberartian/signifikansi regresi secara keseluruhan dengan rumus hipotesis sebagai berikut:

$\mathrm{H}_{0}: \quad \mathrm{b}_{1}=\mathrm{b}_{2}=\mathrm{b}_{3}=\mathrm{b}_{4}=0$, Artinya variasi dari model regresi berhasil menerangkan variasi variabel bebas secara keseluruhan, sejauh mana pengaruhnya terhadap variabel tidak bebas (variabel terikat)

$\mathrm{H}_{\mathrm{a}}: \quad \mathrm{b}_{1} \neq \mathrm{b}_{2} \neq \mathrm{b}_{3} \neq \mathrm{b}_{4} \neq$ 0

Artinya variasi dari model regresi tidak berhasil menerangkan variasi variabel bebas secara keseluruhan, sejauh mana pengaruhnya terhadap variabel tidak bebas (variabel terikat)

Pengujian dengan uji $F$ variansnya adalah dengan membandingkan $F_{\text {hitung }}\left(\mathrm{F}_{\mathrm{h}}\right)$ dengan $F_{\text {tabel }}\left(F_{t}\right)$ pada $\alpha=0,05$ apabila hasil perhitungannya menunjukkan:

a. $\mathrm{F}_{\mathrm{h}}>\mathrm{F}_{\mathrm{t}}$, maka $\mathrm{H}_{0}$ ditolak dan $\mathrm{H}_{\mathrm{a}}$ diterima

Artinya variasi dari model regresi berhasil menerangkan variasi variabel bebas secara keseluruhan, sejauh mana pengaruhnya terhadap variabel tidak bebas (variabel terikat).

b. $\mathrm{F}_{\mathrm{h}}<\mathrm{F}_{\mathrm{t}}$, maka $\mathrm{H}_{0}$ diterima dan $\mathrm{H}_{\mathrm{a}}$ ditolak

Artinya variasi dari model regresi tidak berhasil menerangkan variasi variabel bebas secara keseluruhan, sejauh mana pengaruhnya terhadap variabel tidak bebas (variabel terikat).

\section{Variabel Dominan}

Untuk mengetahui seberapa besar kontribusi masing-masing variabel bebas dan yang paling menentukan (dominan) pengaruhnya terhadap variabel terikat suatu model regresi linier, maka digunakan koefisien Beta (Beta Coefficient) setiap variabel yang distandarisasi (standardized cofficient). Nilai beta $(\beta)$ terbesar menunjukkan bahwa variabel bebas tersebut mempunyai pengaruh yang dominan terhadap variabel terikat. (Sritua, 2012:12).

\section{Hasil Penelitian dan Pembahasan}

Analisis Regresi Berganda Variabel Kompetensi (X1) dan Motivasi (X2) terhadap Kinerja Pegawai (Y).

Sebagaimana telah dirumuskan sebelumya bahwa dalam penelitian ini sesuai dengan hipotesis :

Menurut Sugiyono (2006:168) hipotesis adalah suatu perumusan atau kesimpulan sementara mengenai suatu penelitian yang dibuat untuk menjelaskan penelitian itu dan juga dapat menuntun atau mengarahkan penelitian selanjutnya.

Dari permasalahan yang dikemukakan diatas, maka hipotesis penelitian ini adalah :

1. Secara parsial Kompetensi dan Motivasi Sikap berpengaruh signifikan Terhadap Kinerja Pos Pembinaan Terpadu (POSBINDU) Kabupaten Tabalong.

2. Secara simultan Kompetensi dan Motivasi Sikap berpengaruh signifikan Terhadap Kinerja Pos Pembinaan Terpadu (POSBINDU) Kabupaten Tabalong.

3. Variabel yang mempunyai pengaruh dominan Terhadap Kinerja Pos Pembinaan Terpadu (POSBINDU) Kabupaten Tabalong adalah Kompetensi 
Pengujian dilakukan dengan tingkat kepercayaan $95 \%$ atau tingkat signifikansi $0,05 \quad(\mathrm{a}=0,05)$. Untuk mengkaji kebenaran hipotesis - hipotesis tersebut digunakan analisis regresi linier berganda. Pada analisis regresi ini akan dilakukan uji serentak atau uji $\mathrm{F}$ serta parsial atau uji t.

Tabel 1 Rekapitulasi Analisis Regresi Linier Berganda

Pengaruh Kompetensi (X1), Motivasi (X2) Terhadap Kinerja Pegawai (Y) Pegawai Pos Pembinaan Terpadu (POSBINDU) Kabupaten Tabalong.

\begin{tabular}{|c|c|c|c|c|c|}
\hline Variabel & $\begin{array}{c}\text { Koefisien } \\
\text { Regresi (bi) }\end{array}$ & $\begin{array}{c}\mathrm{t} \\
\text { hitun } \\
\mathrm{g}\end{array}$ & $\begin{array}{c}\mathrm{t} \\
\text { tabe } \\
1\end{array}$ & $\begin{array}{c}\text { Bet } \\
\mathrm{a}\end{array}$ & sig \\
\hline Konstanta & 5,284 & & & & \\
\hline $\begin{array}{l}\text { Kompetens } \\
\text { i (X1) }\end{array}$ & 0,438 & $\begin{array}{c}2,87 \\
7 \\
\end{array}$ & $\begin{array}{l}1,9 \\
92 \\
\end{array}$ & $\begin{array}{l}0,3 \\
53 \\
\end{array}$ & $\begin{array}{l}0,0 \\
05 \\
\end{array}$ \\
\hline $\begin{array}{l}\text { Motivasi } \\
(\mathrm{X} 2)\end{array}$ & 0,203 & $\begin{array}{c}3,56 \\
3 \\
\end{array}$ & $\begin{array}{l}1,9 \\
92 \\
\end{array}$ & $\begin{array}{l}0,4 \\
38 \\
\end{array}$ & $\begin{array}{c}0,0 \\
01 \\
\end{array}$ \\
\hline \multicolumn{2}{|c|}{ Konstanta $=5,284$} & \multicolumn{4}{|c|}{ F hitung $=49,116$} \\
\hline \multicolumn{2}{|c|}{ Multiple $\mathrm{R}=0,749$} & \multicolumn{4}{|c|}{$\mathrm{F}$ tabel $=3,12$} \\
\hline \multicolumn{2}{|c|}{$\mathrm{R}$ square $\left(\mathrm{R}^{2}\right)=0,561$} & \multicolumn{4}{|c|}{ Sig $=0,000$} \\
\hline
\end{tabular}

Pada tabel 1 diatas dapat dilihat $\mathrm{R}$ Square sebesar 0,561 yang berarti besarnya variasi sumbangan seluruh variabel bebas terhadap variabel terikatnya adalah $56,1 \%$ sedangkan sisanya 43,9\% dijelaskan oleh sebab lain diluar dari penelitian ini. Ghozali (2005)

Nilai R Square sebesar 0,561 atau $56,1 \%$ menyatakan korelasi pengaruh variabel bebas Kompetensi (X1) dan Motivasi (X2) Terhadap Kinerja Pegawai (Y) Pegawai Pos Pembinaan Terpadu (POSBINDU) Kabupaten Tabalong yang kuat.

Berdasarkan tabel 1 diatas diperoleh persamaan regresi sebagai berikut:

$Y=5,284+0,438 X 1+0,203 \times 2+$ ei

Adapun penjelasan dari persamaan regresi diatas adalah sebagai berikut :

1. Jika koefisien $0,438 \quad \mathrm{X} 1$ variabel Kompetensi meningkat dengan asumsi Koefisien 0,203 X2 variabel Motivasi tetap, maka Kinerja Pegawai juga akan meningkat.

2. Jika koefisien $0,203 \mathrm{X} 2$ variabel Motivasi meningkat dengan asumsi
Koefisien $\quad 0,438 \quad X 1 \quad$ variabel

Kompetensi tetap maka Kinerja Pegawai juga akan meningkat.

Interpretasi terhadap konstanta $(5,284)$ pengukuan dalam penelitian ini dimana variabel dengan menggunakan skala Likert antara 1 sampai dengan 5 maka tidak boleh diinterpretasikan bahwa jika variabel Kompetensi (X1) dan Motivasi (X2) bernilai nol, karena ketiga variabel tersebut tidak mungkin bernilai nol karena Skala Likert terendah yang digunakan adalah 1 dan berdasarkan hasil perhitungan spss dalam penelitian ini nilai konstanta adalah 5,284 dan termasuk dalam kategori sedang.

Berdasarkan persamaan tersebut, menunjukkan bahwa semua variabel bebas memiliki koefisien regresi positif. Hal ini berarti variabel Kompetensi (X1) dan Motivasi (X2), mempunyai hubungan yang searah atau berbanding lurus dengan variabel terikatnya atau Kinerja Pegawai (Y). Artinya, jika variabel X1 dan X2 mengalami kenaikan maka variabel terikatnya $\mathrm{Y}$ juga ikut mengalami kenaikan, dan jika variabel $\mathrm{X} 1$ dan $\mathrm{X} 2$ mengalami penurunan, maka variabel terikatnya $\mathrm{Y}$ akan mengalami penurunan.

\section{Uji Hipotesis}

1. Uji Hipotesis I: Secara parsial Kompetensi dan Motivasi Sikap berpengaruh signifikan Terhadap Kinerja Pos Pembinaan Terpadu (POSBINDU) Kabupaten Tabalong (Uji t Secara Parsial)

Melalui pengujian ini akan dapat diketahui apakah variabel yang terdiri dari Kompetensi (X1) berpengaruh terhadap Kinerja Pegawai (Y) Pada Pos Pembinaan Terpadu (Posbindu) Kabupaten Tabalong, yaitu dengan cara membandingkan nilai $\mathrm{t}$ hitung dengan $\mathrm{t}$ tabel, pada taraf signifikansi (taraf kepercayaan) $5 \%$ dan rumus derajat bebas/degre of freedom, df $=\mathrm{n}-\mathrm{K}-1=80-3-1=$ 76 maka didapat nilai $\mathrm{t}$ tabel 1,992 . Jika nilai $\mathrm{t}_{\text {hitung }}$ lebih besar dari pada nilai $\mathrm{t}$ tabel maka pengaruhnya signifikan. 
Selain itu juga dapat dilihat besarnya pengaruh masing-masing variabel bebas terhadap variabel terikatnya.

Pengaruh variabel Kompetensi (X1) terhadap Kinerja Pegawai (Y). Kompetensi (X1) berpengaruh signifikan terhadap Kinerja Pegawai (Y) karena nilai $t_{\text {hitung }}(2,877)>t_{\text {tabel }}$ $(1,992)$ sehingga dapat disimpulkan bahwa Kompetensi (X1) berpengaruh siginifikan secara sendiri - sendiri atau parsial terhadap Kinerja Pegawai (Y) pada Pos Pembinaan Terpadu (Posbindu) Kabupaten Tabalong

Pengaruh variabel Motivasi (X2) terhadap Kinerja Pegawai (Y). Motivasi (X2) berpengaruh signifikan terhadap Kinerja Pegawai (Y) karena nilai $t_{\text {hitung }}(3,563)>t_{\text {tabel }}(1,992)$ sehingga dapat disimpulkan bahwa Motivasi (X2) berpengaruh siginifikan secara sendiri - sendiri atau parsial terhadap Kinerja Pegawai (Y) pada Pos Pembinaan Terpadu (Posbindu) Kabupaten Tabalong.

Berdasarkan hasil uji hipotesis diatas maka hipotesis pertama yang mengatakan Secara parsial Kompetensi dan Motivasi Sikap berpengaruh signifikan Terhadap Kinerja Pos Pembinaan Terpadu (POSBINDU) Kabupaten Tabalong adalah benar atau teruji.

2. Uji Hipotesis II : Secara simultan Kompetensi dan Motivasi berpengaruh signifikan Terhadap Kinerja Pos Pembinaan Terpadu (POSBINDU) Kabupaten Tabalong (Uji F Secara Simultan)

Uji ini digunakan dengan tujuan untuk membuktikan apakah variabel bebas berpengaruh secara bersama-sama terhadap variabel terikat. Dalam menjawab hipotesis yang telah diajukan pada awal penelitian, menggunakan alat bantu analisis software SPSS versi 21.00. Dari hasil perhitungan melalui SPSS menunjukan $F_{\text {hitung }}$ sebesar 17,377 dan $F_{\text {tabel }}$ dengan menggunakan tingkat signifikasi (taraf kepercayaan) $5 \%$ dan rumus derajat bebas/degre of freedom, df $1=\mathrm{K}-1=3-1=2$ dan df $2=\mathrm{n}-\mathrm{K}=80-3=77$ maka didapat nilai $F_{\text {tabel }}$ sebesar 3,12. Ini menyatakan bahwa $F_{\text {hitung }}(17,377)>$ $F_{\text {tabel }} \quad(3,12)$. sehingga dapat disimpulkan bahwa Kompetensi (X1) dan Motivasi (X2) berpengaruh signifikan secara simultan Terhadap Kinerja Pegawai (Y) Pos Pembinaan Terpadu (Posbindu) Kabupaten Tabalong

Berdasarkan hasil uji hipotesis kedua diatas maka dapat disimpulkan hipotesis kedua yang mengatakan Secara simultan Kompetensi dan Motivasi berpengaruh signifikan Terhadap Kinerja Pos Pembinaan Terpadu (POSBINDU) Kabupaten Tabalong dapat diterima atau teruji.

3. Uji Hipotesis III: Variabel yang mempunyai pengaruh dominan Terhadap Kinerja Pos Pembinaan Terpadu (POSBINDU) Kabupaten Tabalong adalah Kompetensi (Uji Beta)

Berdasarkan tabel hasil penelitian variabel Motivasi merupakan variabel yang dominan berpengaruh terhadap Kinerja Pegawai Pos Pembinaan Terpadu (Posbindu) Kabupaten Tabalong karena nilai beta variabel X2 0,438 > nilai beta variabel X1 0,353. Maka dapat disimpulkan variabel Motivasi merupakan variabel yang dominan berpengaruh terhadap Kinerja Pegawai Pos Pembinaan Terpadu (Posbindu) Kabupaten Tabalong

Berdasarkan hasil uji hipotesis diatas maka hipotesis ketiga yang mengatakan Variabel yang mempunyai pengaruh dominan Terhadap Kinerja Pos Pembinaan Terpadu (POSBINDU) Kabupaten Tabalong adalah Motivasi adalah benar atau teruji.

\section{Kesimpulan}

Berdasarkan hasil analisis dan pembahasan yang telah diuraikan pada 
bab-bab sebelumnya, maka kesimpulan penelitian ini adalah:

1. Kompetensi dan Motivasi berpengaruh signifikan secara parsial terhadap Kinerja Pegawai Pos Pembinaan Terpadu (POSBINDU) Kabupaten Tabalong.

2. Kompetensi dan Motivasi berpengaruh signifikan secara simultan terhadap Kinerja Pegawai Pos Pembinaan Terpadu (POSBINDU) Kabupaten Tabalong.

3. Motivasi merupakan variabel yang berpengaruh dominan terhadap Kinerja Pegawai Pos Pembinaan Terpadu (POSBINDU) Kabupaten Tabalong.

\section{Daftar Pustaka}

Allport, G, W .2008. Pattern and Growth in Personality Holt,. Rineheart and Winston, Inc. London .

Anwar .2006. Metodologi Penelitian Praktis Untuk Ilmu Sosial dan. Ekonomi, Edisi Pertama, Cetakan Pertama, Penerbit Buntara. Jakarta.

Arikunto, Suharsimi. 2012. Prosedur Penelitian Suatu Pendekatan Praktik. Rineka Cipta .Jakarta .

Azwar . Saifuddin. 2005. Sikap manusia: Teori dan pengukurannya. Pustaka Pelajar. Yogyakarta.

Bodur .2002. The effect of heat application on pain, stiffness, physical function and quality of life in patients with knee oateoarthritis. Journal of Clinical Nursing. 19, 1113-1120.

Boulter, Dalziel dan Hill .1996. People and Competencies, Bidlles, Ltd.London.

Boutler, Nick .2005. People and Competencies: The Route To Competitive Advantage. Terjemahan Gramedia. Jakarta.

Byham, William .2007. The Lightning of Empowerment. Fawcett Books .New York.

Devi Rusvitawati. 2016. Pengaruh Kompetensi Terhadap Kinerja
Karyawan Rumah Sakit Sari Mulia Banjarmasin

Dwiyanti, 2005. tres Kerja Di Lingkungan DPRD Studi Tentang Anggota. DPRD Di Kota Surabaya, Malang, Dan Kabupaten Jember. Jurnal. Masyarakat Jurnal Masyarakat, Kebudayaan dan Politik, 3 : 71-80. Fakultas Kesehatan Masyarakat Universitas Airlangga.

Surabaya.

Fadel, Muhammad .2012 Reinventing Local Government. PT. Elex Media. Komputindo. Jakarta.

Flippo, Edwin. 2000 Manajemen Personalia. Edisi 2. Jakarta : Erlangga

Gerungan W.A..2002. Psychologi Sosial. PT Eresco. Jakarta.

Gie The Liang .2007. Administrasi Perkantoran. Modern Liberty. Yogyakarta.

Hutapea dan Thoha .2008. Kompetensi Plus. PT Gramedia Pustaka Utama. Jakarta.

Irianto .2008. Statistik Konsep Dasar dan Aplikasinya. Kencana. Jakarta.

Martoyo, Susilo .2007., Manajemen Sumber Daya Manusia .edisi 4), dicetak dan diterbitkan BPFE. Yogjakarta.

Matthews, Aalsma .2006 Jurnal Personal Fables, Narcissism, and Adolescent. Adjusment. www.interscience.wiley.com :published online.

Moeheriono, .2009., Pengukuran Kinerja Berbasis Kompetensi, Penerbit Ghalia. Indonesia, Bandung.

Notoadmojo.W ,2005.Pengembangan Sumber Daya Manusia, Rineka Cipta, Jakarta.

Pasolong, Harbani .2012. Teori Administrasi Publik, Alfabeta, Bandung.

Revi Rizki Irawan. 2016 . Pengaruh Kompetensi Pegawai Dan Motivasi Kerja Terhadap Kinerja Perawat Rumah Sakit PTPN VIII Subang 
Rivai, Veizhal .2011. Manajemen Sumber Daya Manusia untuk Perusahaan, PT. Remaja Rosda Karya. Bandung.

Rosyadi dan Muwarti .2005. Efisiensi Penggunaan Sumber Daya .Univ.Padjadjaran.Bandung.

Santoso, Singgih .2005. Statistik Parametik. PT Gramedia Pustaka. Jakarta.

Sears, Francis Weston.2008. Optics, 3rd ed. Massachusetts: AddisonWesley Publishing. Company, Inc.

Siagian, Sondang. P .2012. Manajemen Sumber Daya Manusia. Bumi. Aksara. Jakarta.

Singarimbun .2012. Metode Penelititan Survei. LP3S, Jakarta.

Sritua, 2012. Metodologi Penelitian Ekonomi. UI.Jakarta.

a.
Sugiyono,Dr .2012. Metode Penelitian Kuantitatif Kualitatif dan $R \& D$. Alfabeta. Bandung.

Sultan dan Sevanus Thane. 2016. Pengaruh Kompetensi, Motivasi, Beban Kerja Perawat Pelaksansa Terhadap Kinerja Perawat Diruang Rawat Inap Rumah Sakit Umum Daerah Jayapura

Sunyoto, Danang .2012. Manajemen Sumber Daya Manusia. CAPS. Yogyakarta.

Sutherland dan Wood Worth .2008. Psychology. Holt. New Yok.

Umar, Husein. 2012. Metode Penelitian Untuk Skripsi dan Tesis Bisnis", Raja Grafindo Persada. Jakarta.

Undang-Undang Kesehatan No.23 tahun 1992 tentang Kesehatan

Winardi, 2000. Manajemen Perilaku Organisasi , Edisi Revisi, Kencana. Prenada Media Group. Jakart 